\title{
Co-occurrence of latent Dickeya and Pectobacterium species in potato seed tuber samples from northern Finland
}

\author{
Yeshitila Degefu \\ Natural Resources Institute Finland, Paavo Havaksen tie 3, P. O. Box 413, 90014 University of Oulu, Finland \\ e-mail: yeshitila.degefu@luke.fi
}

\begin{abstract}
Recent methodological developments have uncovered the etiological diversity of the potato blackleg and soft rot Pectobacteriaceae. At least five species in the genera Dickeya and Pectobacterium have been confirmed to cause blackleg on potatoes in Finland. The bacteria are seed borne and remain latent in the tuber until conditions favourable for growth, multiplication and infection prevail. Tubers could be infected by one or more of these species. This short communication is based on the results of molecular detection data collected for more than 14 years from potato seed lots produced in Finland. Diagnostic PCR assay specific to Dickeya solani, Pectobacterium atrosepticum, Pectobacterium carotovorum, $P$. brasiliense and $P$. parmentieri revealed that potatoes are infected by one or more of these species; it also revealed that single species infection is more common than multiple colonization. An event of simultaneous occurrences of different strains from the Pectobacterium species appears to be more frequent than that observed between Dickeya and Pectobacterium species. The absence of co-occurrence of Dickeya solani and Pectobacterium atrosepticum is intriguing.
\end{abstract}

Key words: blackleg, soft rot, seed potato, Dickeya, Pectobacterium, co-occurrence, molecular detection

\section{Introduction}

The enterobacteria in the genera Dickeya and Pectobacterium belonging to the recently established Pectobacteriaceae family (Adeolu et. al. 2016) are the primary causes of blackleg and soft rot on potatoes. According to the survey by the journal of Molecular Plant Pathology (Mansfield et al. 2012), Dickeya and Pectobacterium spp. have been ranked among the top ten bacterial plant pathogens in terms of economic and scientific importance.

Advances in molecular biology and genomics have revealed high genetic diversity in both genera. As a result, the taxonomy of Dickeya and Pectobacterium has undergone significant revision in recent years. This includes the establishment of new species and transfer of strains to new species (Samson et al. 2005, Pasanen et al. 2013, van der Wolf et al. 2014, Khay et al. 2016, Dees et al. 2017, Motyka et al. 2017, Portier et al. 2020). Species previously indistinguishable from each other and misclassified as $P$. carotovorum have now been readily identified by using molecular methods (Nykyri et al. 2012, Khayi et al. 2016, Potrykus et al. 2016, Pritchard et al. 2016). The observed etiological diversity causes diagnostic complexity and increases the cost of laboratory seed testing. Since these species cause symptoms on potatoes indistinguishable from each other, visual inspection as a method of seed certification and pathogen identification is currently not reliable.

To date polymerase chain reaction (PCR) is widely used for species-specific detection and diagnosis of the blackleg Pectobacteriaceae (Degefu et al. 2009, Czajkowski et al. 2015). As a result, as many as six species, namely D. dianthicola, D. solani, P. atrosepticum, P. brasiliense, P. carotovorum and P. parmentieri (formerly P. wasabiae), are known as main and common causes of blackleg and soft rot in Europe including Finland (Laurila et al. 2010, Toth et al. 2011, Tsror et al. 2011, Moleleki et al. 2012, Czajkowski et al. 2015, Degefu et al. 2013, Potrykus et al. 2016, Zoledowska et al. 2018). New species of Pectobacterium, namely P. punjabense (Sarfras et al. 2018), P. polaris (Dees et al. 2017) and most recently P. parvum (Pasanen et al. 2020) have been discovered in Finland, but information on the prevalence and economic importance of these emerging new species on potato production in Finland is very limited or lacking. The bacteria are seed borne and survival outside the host plant is very poor.

Studies have revealed that temperature plays an important role in growth and pathogenic differentiation of the blackleg Pectobacteriaceae (Pérombelon and Kelman 1980, Pérombelon et al. 1987, Pérombelon 1992, Tsror et al. 2009, Duarte et al. 2004, van der Merwe et al. 2010, Tsror et al. 2013, Golanowska et al. 2017). From an in vitro study, du Raan et al. 2016 reported that there are differences in optimal temperatures among the species and isolates within the species. However, most of the reports available to date regarding the optimal temperature are 
generated from in vitro studies, not supported by greenhouse or field data. Despite these, there is not much dispute that temperature plays an important role in species selection and pathogenicity of the potato blackleg pathogens (du Raan 2016 and references therein).

According to years of ecological and epidemiological studies, it has become evident that blackleg is a disease complex or a disease syndrome of a worldwide threat to potato production and a disease which has become cumbersome and costly to diagnose and control (Degefu et al. 2016). In complex diseases, more than one species is involved in the expression of the characteristic disease symptom on the plant tissue and plant organ they invade and it is a widely accepted current concept that such plant pathogens interact either synergically or antagonistically (Le May et al. 2009). Therefore, it is reasonable to argue that the same mechanism governs the blackleg Pectobacteriaceae and potato pathosystem in field infections and in laboratory enrichment culturing. However, detailed investigation of these phenomenona and the impact on potato health and diagnostics is needed.

Moreover, reports have started to emerge that $D$. solani and $P$. carotovorum produce bacteriocin and bacteriocin-like substances which are inhibitory to other closely related bacteria (Holtsmark et al. 2008, Garlant et al. 2013, Kazemi-Zaromi et al. 2015). Currently, more efforts are being made to identify more of these substances. However, information on the level of toxicity of these secreted substances and their ability to counteract the other related species is lacking.

The aim of this study is to analyse the occurrence/co-occurrence of the commonly known destructive blackleg and soft rot enterobacteria as a step towards obtaining a basic understanding of the meaning of the etiological diversity of the pathosystem, as one development tool for the diagnosis and integrated management of the disease.

\section{Materials and methods}

Seed lots submitted for certification and samples collected during annual surveys from the High Grade seed po-

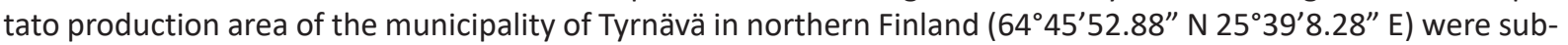
jected to species-specific diagnostic PCR detection and identification tests. Pre-PCR and post-PCR procedures were as described in Degefu et al. (2009). Both real-time qPCR and conventional or endpoint PCR were employed for the detection of the latent bacteria in the seed tubers. A working sample of one hundred tubers randomly picked from the total of two hundred submitted tuber samples were tested for latent Dickeya and Pectobacterium species using species-specific primers and probes (Tables $1 \& 2$ ). Primers were used in the endpoint PCR (Table 1) and primers and probes were used in real-time PCR (Table 2). The PCR programs and reaction mixes were as described in Degefu et al. (2009). Seed lots which tested positive for the bacteria were identified and the species detected in each sample (single species or co-occurring) were recorded. Tests made for $P$. brasiliense and $P$. parmentieri were limited to the last three or four years of the project period since the two species had been appearing on potatoes in Finland since 2015. Therefore, there was not sufficient data from these new and emerging species to make meaningful comparisons.

\section{Results}

Fourteen years (2004-2018) of PCR-based detection and diagnosis of latent soft rot and blackleg enterobacteria, namely Dickeya and Pectobacterium spp. in seed potatoes cultivated in Finland, revealed that potatoes are infected by one or more species of the bacteria. The test results from 1058 Dickeya and Pectobacterium spp.-positive samples revealed an interesting single species and simultaneous or co-colonization scenarios. The results demonstrated that single species infection is more common ( $82 \%$ of samples) than multiple species or co-infection (Table 3 ). In an event of co-colonization of tubers, Pectobacterium-Pectobacterium co-occur more frequently than the Dickeya-Pectobacterium combination. P. atrosepticum and $P$. carotovorum co-occurred more frequently, followed by $D$. solani and $P$. carotovorum. To a lesser extent, co-habitation of all three $(D$. solani, $P$. atrosepticum and $P$. carotovorum) was also noted. Only one case of $D$. solani-P. atrosepticum was detected during the fourteen-year test period. Tests from potato stem segments with blackleg symptoms also revealed similar scenarios, but the study was carried out extensively on tubers. 
Table 1. Primers used in endpoint PCR

\begin{tabular}{|c|c|c|c|c|}
\hline Specificity & Primer & Sequence $5^{\prime}-3^{\prime}$ & Annealing temp & References \\
\hline \multirow[t]{2}{*}{ Dickeya spp. } & ADE 1 & GATCAGAAAGCCGCAGCCAGAT & \multirow[t]{2}{*}{$72{ }^{\circ} \mathrm{C}$} & \multirow[t]{2}{*}{ Nassar et al. 1996} \\
\hline & ADE2 & TGTGGCCGATCAGGATGGTTTTGTCGTGC & & \\
\hline \multirow[t]{2}{*}{ P. atrosepticum } & Eca $1 F$ & CGGCATCATAAAAACACG & \multirow[t]{2}{*}{$55^{\circ} \mathrm{C}$} & \multirow[t]{2}{*}{ De Boer and Ward 1995} \\
\hline & Eca $2 R$ & GCACACTTCATCCAGGGA & & \\
\hline \multirow[t]{2}{*}{ P. brasiliense } & BR1F & GCGTGCCGGGTTTATGACCT & \multirow[t]{2}{*}{$62^{\circ} \mathrm{C}$} & \multirow[t]{2}{*}{ Duarte et al. 2004} \\
\hline & L1R & CAGGGCATCCACCGT & & \\
\hline \multirow{2}{*}{$\begin{array}{l}\text { P. parmentieri } \\
\text { (formerly wasabiae) }\end{array}$} & $\mathrm{PhF}$ & GGTTCAGTGCGTCAGGAGAG & \multirow[t]{2}{*}{$60^{\circ} \mathrm{C}$} & \multirow[t]{2}{*}{ De Boer et al. 2012} \\
\hline & $\mathrm{PhR}$ & GCGGAGAGGAAGCGGTGAAG & & \\
\hline \multirow[t]{4}{*}{ P. carotovorum } & Ec001F & GGTTACGATCAGCG TCTCG & \multirow[t]{2}{*}{$60^{\circ} \mathrm{C}$} & \multirow[t]{2}{*}{ MTT, unpublished } \\
\hline & Ec001R & GATGTGCCGATGCCGATAC & & \\
\hline & EXPCC F & GAACTTCGCACCGCCGACCTTCTA & \multirow[t]{2}{*}{$60^{\circ} \mathrm{C}$} & \multirow[t]{2}{*}{ Kang et al. 2003} \\
\hline & EXPCCR & GCCGTAATTGCCTACCTGCTTAAG & & \\
\hline
\end{tabular}

Table 2. Primers and probes used in real time quantitative PCR (QPCR)

\begin{tabular}{|c|c|c|c|}
\hline Specificity & Primer/probe & Sequence $5^{\prime}-3^{\prime}$ & References \\
\hline \multirow[t]{3}{*}{ D. solani } & SOL-C-F & GCCTACACCATCAGGGCTAT & \multirow[t]{3}{*}{ Pritchard et al. 2013} \\
\hline & SOL-C-R & ACACTACAGCGCGCATAAAC & \\
\hline & SOL-C-P & FAM-CCAGGCCGTGCTCGAAATCC-TAMRA & \\
\hline \multirow[t]{3}{*}{ D. dianthicola } & DIA-A-F & GGCCGCCTGAATACTACATT & \multirow[t]{3}{*}{ Pritchard et al. 2013} \\
\hline & DIA-A-R & TGGTATCTCTACGCCCATCA & \\
\hline & DIA-A-P & FAM-ATTAACGGCGTCAACCCGGC-TAMRA & \\
\hline \multirow[t]{3}{*}{ P. atrosepticum } & ECA-F & CGGCATCATAAAAACACGCC & \multirow[t]{3}{*}{ De Boer and Ward 1995} \\
\hline & ECA-R & CCTGTGTAATATCCGAAAGGTGG & \\
\hline & ECA-P & FAM-ACATTCAGGCTGATATTCCCCCTGCC-TAMRA & \\
\hline \multirow[t]{3}{*}{ P. brasieliense } & PBR-F & Not released & \multirow[t]{3}{*}{ van der Waals } \\
\hline & PBR-R & Not released & \\
\hline & PBR-P & Not released & \\
\hline \multirow[t]{3}{*}{ P. parmentieri } & PwF1 & TCTGTTCAATGTCAACGCAGGTA & \multirow[t]{3}{*}{ van der Wolf , unpublishec } \\
\hline & PwR1 & AGGTAACCGCAATTTGCTCAA & \\
\hline & PwP1 & FAM-TGTGCGCAACCTG-MGB & \\
\hline
\end{tabular}

\section{Discussion}

During the last three decades, blackleg in Finland has undergone significant transformation with respect to the diversity of the causal bacteria (Harju and Kankila 1993, Degefu 2015, Degefu et al. 2013, Degefu and Virtanen 2015, Degefu 2016). The Dickeya and Pectobacterium species, which have not been known in Finland, have emerged as consistent threats to potato production (Degefu et al. 2013). Climate change is believed to be the major factor for the observed new scenario. The northward extension of some tropical and sub-tropical species and the southward expansion of the cooler and temperate species have been considered the reasons for the changing face and global dimension of blackleg and soft rot on potatoes. Advances in molecular diagnostics facilitated the monitoring, detection, and diagnosis of the disease. As a result, during the last fourteen years the introduction, establishment, and incidence of Dickeya and Pectobacterium on potatoes in Finland, northern Finland in particular, have been closely monitored. While $P$. atrosepticum and $P$. carotovorum have long been known as blackleg and soft rot bacteria on potatoes in Finland, $D$. solani, $P$. brasiliense, and $P$. parmentieri are some of the recently emerged or re-emerged and potentially destructive potato pathogens in Finland.

This PCR-based detection study confirmed that potatoes could be infected by one or more of these known blackleg or soft rot-causing pathogens, causing characteristic symptoms that are indistinguishable from each other. It has also become evident that infection by single species is more common than colonization by multiple species, suggesting that the bacteria compete to varying degrees. This is consistent with the common understanding that 
co-occurring pathogens interact either synergistically or antagonistically in their ecological niche (Le May et al. 2009, Lamichhane and Venturi 2015). The data collected from about a decade and half of molecular (PCR) diagnostics and detection of latent Dickeya and Pectobacterium species in potato seed lots produced in Finland revealed interesting co-occurrence phenomena (Table 3 ). The near lack (only one) of co-occurrence of $D$. solani and $P$. atrosepticum during the fourteen years of investigation (Table 3 ) is intriguing. The phenomenon was consistent throughout the fourteen years of investigation, so it is unlikely that it occurred by chance. The most recent genomic study (Motyka-Pomagruk et al. 2021) revealed some peculiar gene pools specific to $D$. solani, which might contribute to the occupation of an isolated ecological niche by this particular species.

\begin{tabular}{lcc}
\multicolumn{2}{c}{ Table 3. Occurrence of latent Dickeya and Pectobacterium species in potato seed lots produced in Finland } \\
\hline Species identification & Number of positive seed lots & Percentage out of total samples \\
\hline Dickeya solani (DS) & 114 & 11.0 \\
Pectobacterium atrosepticum (PCA) & 201 & 19.0 \\
Pectobacterium carotovorum (PCC) & 550 & 52.0 \\
PCA + PCC & 115 & 11.0 \\
DS + PCC & 53 & 5.0 \\
DS + PCA + PCC & 24 & 2.23 \\
DS + PCA & 1 & 0.09
\end{tabular}

The two species exhibit contrasting temperature optimums for pathogenicity and growth (Pérombelon and Kelman 1980, Pérombelon et al. 1987, du Raan et al. 2016). P. atrosepticum, which has been the major cause of blackleg on potatoes in Finland and other cooler regions of northern Europe, thrives best at cooler temperatures, lower than $25^{\circ} \mathrm{C}$, although there are reports that it can survive at temperatures of up to $37^{\circ} \mathrm{C}$ (Pérombelon et al. 1979 , Pérombelon 1992). On the other hand, $D$. solani is more prevalent and causes severe blackleg outbreaks at temperatures above $25^{\circ} \mathrm{C}$ (Elphinstone and Toth 2007, Degefu et al. 2013). It is, therefore, reasonable to argue that growing season temperature has a significant impact on pathogenicity differentiation and species selection, specifically in these two species. However, reports from several studies indicate that the cardinal, optimal and growth range temperatures of the blackleg enterobacteria appeared to overlap (du Raan et al. 2016), making it difficult to draw a well-defined demarcation and justify temperature as a sole mechanism for such strong species selection (Pérombelon et al. 1979, Molina and Harrison 1980, Pérombelon and Kelman 1980, Pérombelon et al. 1987, du Raan et al. 2016, Abdullah et al. 2017). For example, the growth temperature range for $P$. atrosepticum is $18-31^{\circ} \mathrm{C}$, while that of $D$. solani is $24-42^{\circ} \mathrm{C}$.

Another important concept which draws attention is the unique ability of $D$. solani to outcompete or overtake the Pectobacterium species and its relatively higher aggressiveness in causing disease symptoms from lower inoculum levels compared to other species (Toth et al. 2011). The reason for these abilities is not fully known. Bacteriocins and bacteriocin-like substances reviewed in the introduction have been implicated as possible factors. According to current knowledge, bacteriocins are not reported from $P$. atrosepticum. This might explain the reason for the unique phenomena-the lack of co-occurrence of $D$. solani and $P$. atrosepticum observed in this study. On the other hand, the co-occurrence event observed among $D$. solani, $P$. atrosepticum and $P$. carotovorum, and $P$. carotovorum and $D$. solani, although not very frequent (Table 3 ), suggests that bacteriocin and bacteriocin-like substances might play a role in the co-habitation ability among these species. It is rather tempting to suggest that in these three species' co-occurrence, the presence of $P$. carotovorum might play a role in buffering the selection strength of the system due to its ability to produce bacteriocin. However, the role and mechanisms of action of toxins and bacteriocins of $D$. solani and $P$. carotovorum are less investigated. Therefore, at this stage experimental evidence is lacking to confirm the assumptions.

The observed strong species selection between $D$. solani and $P$. atrosepticum might take place in the field because of growing season temperature or as a result of chemical or bacteriocin actions at the time of in vitro enrichment culturing in the PCR detection procedure (Degefu et al. 2009). It is, therefore, a subject of investigation that is vital for advancement in the development of diagnostics for assessment of the prevalence of the bacteria in potatoes.

In conclusion, this research note provides a starting point for investigations on the interactions among the potato-blackleg Pectobacteriaceae pathosystem in an effort to find innovative solutions for effective diagnosis and integrated management of these pathogens which have become consistent global threats to potato production. 


\section{Acknowledgements}

This study was supported by projects financed by the Ministry of Agriculture and Forestry of Finland (MMM) for enhancing the development of the seed potato sector and safeguarding the EU granted High Grade (HG) status of Finland for seed potato production.

\section{References}

Abdullah, A.S., Moffat, G.S., Lopez-Ruiz, F.J., Gibberd, M.R., Hamblin, J. \& Zerihun, A. 2017 Host- multi-pathogen warfare: Pathogen interactions in co-infected plants. Frontiers in Plant Science 8: 1-12. https://doi.org/10.3389/fpls.2017.01806

Adeolu, M., Alnajar, S., Naushad, S. \& Gupta, R.S. 2016. Genome-based phylogeny and taxonomy of the 'Enterobacteriales': proposal for Enterobacterales ord. nov. divided into the families Enterobacteriaceae, Erwiniaceae fam. nov., Pectobacteriaceae fam. nov., Yersiniaceae fam. nov., Hafniaceae fam. nov., Morganellaceae fam. nov., and Budviciaceae fam. nov. International Journal of Systematic and Evolutionary Microbiology 66: 5575-5599. https://doi.org/10.1099/ijsem.0.001485

Czajkowski, R., Pérombelon, M.C.M., Jafra, S., Lojkowska, E., Potrykus, M., van der Wolf, J.M. \& Sledz, W. 2015. Detection, identification, and differentiation of Pectobacterium and Dickeya species causing potato blackleg and tuber soft rot: a review. Annals of Applied Biology 166: 18-38. https://doi.org/10.1111/aab.12166

De Boer, S.H. \& Ward, L.J. 1995. PCR detection of Erwinia carotovora subsp. atroseptica associated with potato tissue. Phytopathology 85: 854-858. https://doi.org/10.1094/Phyto-85-854

Dees, M.V., Lysøe, E., Rossmann, S., Perminow, P.J. \& Brurberg, M.B. 2017. Pectobacterium polaris sp. nov. isolated from potato (Solanum tuberosum). International Journal of Systematic and Evolutionary Microbiology 67: 5222-5229.

https://doi.org/10.1099/ijsem.0.002448

Degefu, Y. 2015. Dickeya and Pectobacterium species: consistent threats to potato production in Europe. https://pdfs.semanticscholar.org/f467/7adbb104019dc6861f7152d70088bb289e89.pdf? ga=2.231970975.1435437946.15738020071690053651.1573802007. (Accessed 15 November 2020).

Degefu, Y. 2016. Monitoring Dickeya and Pectobacterium species in the High-Grade seed potato production area of Finland. Annual Report Ministry of Agriculture and Forestry (MMM) Finland. 12 .

http://urn.fi/URN:NBN:fi-fe201604059033,http://jukuri.luke.fi/handle/10024/532300 (Verified on 5 December 2019).

Degefu, Y., Potrykus, M., Golanowska, M., Virtanen, E. \& Lojkowska, E. 2013. A new clade of Dickeya spp. plays a major role in potato blackleg outbreaks in North Finland. Annals of Applied Biology 162: 231-241. https://doi.org/10.1111/aab.12020

Degefu, Y. \& Virtanen, E. 2015. A decade of monitoring, detection, and characterization of Dickeya and Pectobacterium species in the High-Grade seed potato growing area of Finland: an overview. Tuottava Peruna 2: 22-24.

Degefu, Y., Virtanen, E. \& Väyrynen, T. 2009. Pre-PCR processes in the molecular detection of blackleg and soft rot Erwiniae in seed potatoes. Journal of Phytopathology 157: 370-378. https://doi.org/10.1111/j.1439-0434.2008.01504.x

Duarte, V., De Boer, S.H., Ward, L.J. \& De Oliveira, A.M.R. 2004. Characterization of atypical Erwinia carotovora strains causing blackleg of potato in Brazil. Journal of Applied Microbiology 96: 535-545. https://doi.org/10.1111/j.1365-2672.2004.02173.x

du Raan, S., Coutinho, T.A. \& van der Waals, J.E. 2016. Cardinal temperature differences, determined in vitro, between closely related species and subspecies of pectinolytic bacteria responsible for blackleg and soft rot on potatoes. European Journal of Plant Pathology 144: 361-369.https://doi.org/10.1007/s10658-015-0773-x

Elphinstone, J.G. \& Toth, I.K. 2007. Erwinia chrysanthemi (Dickeya spp.) The facts. In the homepage of British Potato Council Publications. www.potato.org.uk. (Accessed on 11 November 2020)

Garlant, L., Koskinen, P., Rouhiainen, L., Laine, P., Paulin, L., Auvinen, P., Holm, L. \& Pirhonen, M. 2013. Genome Sequence of Dickeya solani, a New soft Rot Pathogen of Potato, Suggests its Emergence May Be Related to a Novel Combination of Non-Ribosomal Peptide/Polyketide Synthetase Clusters. Diversity 5: 824-842. https://doi.org/10.3390/d5040824

Golanowska, M., Kielar, J. \& Lojkowska, E.2017. The effect of temperature on the phenotypic features and the maceration ability of Dickeya solani strains isolated in Finland, Israel, and Poland. European Journal of Plant Pathology 147: 803-817. https://doi.org/10.1007/s10658-016-1044-1.

Harju, P. \& Kankila, J. 1993. Erwinia carotovora contamination of Finnish seed potatoes and the prevalence of bacterial subspecies and serogroups. Agricultural Sciences in Finland 2: 345-352. https://doi.org/10.23986/afsci.72657

Holtsmark, I., Eijsink, V.G.H. \& Brurberg, M.B. 2008. Bacteriocins from plant pathogenic bacteria. FEMS Microbiology Letters 280: 1-7. https://doi.org/10.1111/j.1574-6968.2007.01010.x

Kang, H.W., Kwon, S.W. \& Go, S.J. 2003. PCR based and sensitive detection of Pectobacterium carotovorum by primers generated from URP-PCR fingerprinting-derived polymorphic band. Plant Pathology 52: 127-133. https://doi.org/10.1046/j.1365-3059.2003.00822.x

Kazemi-Zaromi, S., Baghaee-Ravari, S., Khodaygan, P. \& Falahati-Rastegar, M. 2015. Screening bactericidal effect of Pectobacterium carotovorum subsp. carotovorum strains against causal agent of potato soft rot. Journal of Basic Microbiology 56: 196-205. https://doi.org/10.1002/jobm.201500482

Khayi, S., Cigna, J., Chong, T.M., Laurent, A., Chan, K.G., Hélias, V. \& Faure, D. 2016. Transfer of the potato plant isolates Pectobacterium wasabiae to Pectobacterium parmentieri sp.nov. International Journal of Systematic and Evolutionary Microbiology 66 : 5379-5383. https://doi.org/10.1099/ijsem.0.001524 
Lamichhane, J.M. \& Venturi, V. 2015. Synergisms between microbial pathogens in plant disease complexes: a growing trend. Frontiers in Plant Science 6: 85. https://doi.org/10.3389/fpls.2015.00385

Laurila, J., Hannukkala, A., Nykyri, J., Pasanen, M., Hẻlias, V., Garlant, L. \& Pirhonen M. 2010. Symptoms and yield reductions caused by Dickeya species strains isolated from potato and river water in Finland. European Journal of Plant Pathology 126: 249262. https://doi.org/10.1007/s10658-009-9537-9

Le May, C., Potage, G., Andrivon, D., Bernard, A.T. \& Outreman, Y. 2009. Plant Disease Complex: antagonism and synergism between pathogens of the Ascochyta blight Complex on Pea. Journal of Phytopathology 157: 715-721. https://doi.org/10.1111/j.1439-0434.2009.01546.x

Mansfield, J., Genin, S., Magori, S., Citovsky, V., Sriariyanum, M., Ronald, P., Dows, M., Verdier, V., Beer, S.V., Machados, M.A., Toth, I., Salmond, G. \& Foster, G.D. 2012. Top 10 plant pathogenic bacteria in molecular plant pathology. Molecular Plant Pathology 13 614-629. https://doi.org/10.1111/j.1364-3703.2012.00804.x

Moleleki, L.N., Onkendi, E.M., Mongae, A. \& Kubheka, G.C. 2012. Characterisation of Pectobacterium wasabiae causing blackleg and soft rot diseases in South Africa. European Journal of Plant Pathology 135: 279-288. https://doi.org/10.1007/s10658-012-0084-4

Molina, J.J. \& Harrison, M.D. 1980. The role of Erwinia carotovora in the epidemiology of potato blackleg. II. The effect of soil temperature on disease severity. American Potato Journal 57: 351-363. https://doi.org/10.1007/BF02854325

Motyka, A., Zoledowska, S., Sledz, W. \& Lojkowska, E. 2017. Molecular methods as tools to control plant diseases caused by Dickeya and Pectobacterium spp: A minireview. New Biotechnology 39: 181-189. https://doi.org/10.1016/j.nbt.2017.08.010

Motyka-Pomagruk, A., Zoledowska, S., Misztak, A.E., Sledz, W., Mengoni, A. \& Lojkowska, E. 2021. Comparative genomics and pangenome-oriented studies reveal high homogeneity of the agronomically relevant enterobacterial plant pathogen Dickeya solani. BMC Genomics 21: 449. https://doi.org/10.1186/s12864-020-06863-w

Nassar, A., Darrasse, A., Lemattre, M., Kotoujansky, A., Dervin, C., Vedel, R. \& Bertheau, Y. 1996. Characterization of Erwinia chrysanthemi by pectolytic isozyme polymorphism and restriction fragment length polymorphism analysis of PCR amplified fragment of pel genes. Applied and Environmental Microbiology 62: 2228-2235. https://doi.org/10.1128/AEM.62.7.2228-2235.1996

Nykyri, J., Niemi, O., Koskinen, P., Nokso-Koivisto, J., Pasanen, M., Broberg, M., Plyusnin, I., Törönen, P. \& Holm, L. 2012. Revised phylogeny and novel acquired virulence determinants of the model soft rot phytopathogen Pectobacterium wasabiae SCC3193. PLoS Pathog 8 e1003013. https://doi.org/10.1371/journal.ppat.1003013

Pasanen, M., Laurila, J., Brader, G., Palva, E.T., Ahola, V., van der Wolf, J., Hannukkala, A. \& Pirhonen, M. 2013. Characterization of Pectobacterium wasabiae and Pectobacterium carotovorum subsp. carotovorum isolates from diseased potato plants in Finland. Annals of Applied Biology 163: 403-419. https://doi.org/10.1111/aab.12076

Pasanen, M., Waleron, M., Schott, T., Cleenwerck, I., Misztak, A., Waleron, K., Pritchard, L., Ramadan, B.R., Degefu, Y., van der Wolf, J., Vandamme, P. \& Pirhonen, M. 2020. Pectobacterium parvum sp. nov., having a Salmonella SPI-1-like Type III secretion system and low virulence. International Journal of Systematic and Evolutionary Microbiology 70: 2440-2448. https://doi.org/10.1099/ijsem.0.004057

Pérombelon, M.C.M. 1992. Potato blackleg: Epidemiology, host-pathogen interaction and control. Netherlands Journal of Plant Pathology 98: 135-146. https://doi.org/10.1007/BF01974480

Pérombelon, M.C.M., Gullings-Handley, J. \& Kelman, A. 1979. Population dynamics of Erwinia carotovora and pectolytic clostridia in relation to decay of potatoes. Phytopathology 69: 167-173. https://doi.org/10.1094/Phyto-69-167

Pérombelon, M.C.M. \& Kelman, A. 1980. Ecology of the soft rot erwinias. Annual Review of Phytopathology 18: 361-387. https://doi.org/10.1146/annurev.py.18.090180.002045

Pérombelon, M.C.M., Lumb, V.M. \& Zutra, D. 1987. Pathogenicity of soft rot erwinias to potato plants in Scotland and Israel. Journal of Applied Bacteriology 63: 73-84. https://doi.org/10.1111/j.1365-2672.1987.tb02420.x

Portier, P., Pédron, J., Taghouti, G., Dutrieux, C. \& Barny, M.A. 2020. Updated Taxonomy of Pectobacterium Genus in the CIRMCFBP Bacterial Collection: When Newly Described Species Reveal “Old” Endemic Population. Microorganisms 8: 1441. https://doi.org/10.3390/microorganisms8091441

Potrykus, M., Golanowska, M., Sledz, W., Zoledowska, S., Motyka, A., Kolodziejska, A., Butrymowicz, J. \& Lojkowska, E. 2016. Biodiversity of Dickeya spp. isolated from potato plants and water sources in temperate climate. Plant Disease 100: 408-417. https://doi.org/10.1094/PDIS-04-15-0439-RE

Pritchard, L., Glover, R.H., Humphris, S., Elphinstone, J.G. \& Toth, I.K. 2016. Genomics and taxonomy in diagnostics for food security: soft rotting enterobacterial plant pathogens. Analytical Methods 8: 12-24. https://doi.org/10.1039/C5AY02550H

Pritchard, L., Humphris, S., Saddler, G.S., Parkinson, N.M., Bertrand ,V., Elphinstone, J.G. \& Toth, I.K. 2013. Detection of phytopathogens of the genus Dickeya using a PCR primer prediction pipeline for draft bacterial genomic sequences. Plant Pathology 62 587-596. https://doi.org/10.1111/j.1365-3059.2012.02678.x

Samson, R., Legendre J.B., Christen, R., Fischer-Le Saux, M., Achouak, W. \& Gardan, L. 2005. Transfer of Pectobacterium chrysanthemi (Burkholder et al. 1953) Brenner et al. 1973 and Brenneria paradisiaca to the genus Dickeya gen. nov. as Dickeya chrysanthemi comb. nov. and Dickeya paradisiaca comb. nov. and delineation of four novel species, Dickeya dadantii sp. nov., Dickeya dianthicola sp. nov., Dickeya dieffenbachiae sp. nov. and Dickeya zeae sp. nov. International Journal of Systematic and Evolutionary Microbiology 55: 1415-1427. https://doi.org/10.1099/ijs.0.02791-0

Sarfras, S., Riaz, K., Oulghazi, S., Cigna, J., Sahi, S.T., Khan, S.H. \& Faure, D. 2018. Pectobacterium punjabense sp. nov., isolated from blackleg symptoms of potato plants in Pakistan. International Journal of Systematic and Evolutionary Microbiology 68: 3551-3556. https://doi.org/10.1099/ijsem.0.003029

Toth, I.K., van Der Wolf, J.M., Saddler, G., Lojkowska, E., Hẻlias, V., Pirhonen, M., Tsror (Lahkim), L. \& Elphinstone, J.G. 2011. Dickeya species: an emerging problem for potato production in Europe. Plant Pathology 60: 385-99. https://doi.org/10.1111/j.13653059.2011.02427.x 
Tsror (Lahkim), L., Erlich, O., Lebiush, S., Hazanovsky, M., Zig, U., Sławiak,M., Grabe, G., van Der Wolf, J.M. \& van de Haar, J.J. 2009 Assessment of recent outbreaks of Dickeya sp. (syn. Erwinia chrysanthemi) slow wilt in potato crops in Israel. European Journal of Plant Pathology 123: 311-320. https://doi.org/10.1007/s10658-008-9368-0

Tsror (Lahkim), L., Ben-Daniel, B., Chalupowicz, L., van der Wolf, J.M., Lebiush, S., Erlich, O., Dror, O., Barel, V., Nijhuis, E. \& Manulis-Sasson, S. 2013. Characterization of Dickeya strains isolated from potato grown under hot-climate conditions. Plant Pathology 62: 1097-1105. https://doi.org/10.1111/ppa.12030

van der Merwe, J.J., Coutinho, T.A., Korsten, L. \& van der Waals, J.E. 2010. Pectobacterium carotovorum subsp. brasiliensis causing blackleg on potatoes in South Africa. European Journal of Plant Pathology 126: 175-185.https://doi.org/10.1007/s10658-009-9531-2

van der Waals, J.E., Krüger, K., Franke, A.C., Haverkort, A.J. \& Steyn, J.M. 2013. Climate change and potato production in contrasting South African agro-ecosystems 3. Effects on relative Development rates of selected pathogens and pests. Potato Research 56 : 67-84. https://doi.org/10.1007/s11540-013-9231-3

van der Wolf, J.M., Nijhuis, E.H., Kowalewska, J.M., Saddler, G.S., Parkinson, N., Elphinstone, J.G., Pritchard, L., Toth, I.K., Lojkowska, E., Potrykus, M., Malgorzata, G., Waleron, M., de Vos. P., Cleenwerck, I., Pirhonen, M., Garlant, L., Hélias, V., Pothier, J.F., Pfluger, V., Duffy, B., Tsror, L. \& Manulis, S. 2014. Dickeya solani sp. nov., a pectinolytic plant-pathogenic bacterium isolated from potato (Solanum tuberosum). International Journal of Systematic and Evolutionary Microbiology 64: 768-774. https://doi.org/10.1099/ijs.0.052944-0

Zoledowska, S., Motyka-Pomagruk, A., Sledz, W., Mengoni, A., \& Lojkowska, E. 2018. High genomic variability in the plant pathogenic bacterium Pectobacterium parmenieri deciphered from de novo assembled complete genomes. BMC Genomics 19: 751. https://doi.org/10.1186/s12864-018-5140-9 